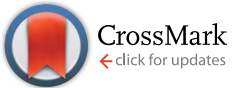

Cite this: RSC Adv., 2017, 7, 7753

Received 10th November 2016 Accepted 9th January 2017

DOI: 10.1039/c6ra26611h

www.rsc.org/advances

\title{
Synthesis of 2-substituted benzo[b]thiophene via a Pd-catalyzed coupling of 2-iodothiophenol with phenylacetylene $\uparrow$
}

\author{
Jingwen Chen, ${ }^{\text {Haifeng Xiang, }{ }^{\text {*a }} \text { Li Yang }}{ }^{\text {ab }}$ and Xiangge Zhou ${ }^{* a}$ \\ A Pd(॥)-catalyzed Sonogashira type cross-coupling reaction between 2-iodothiophenol and \\ phenylacetylene has been developed. A series of 2-substituted benzo[b]thiophenes were obtained in \\ moderate to good yield (up to $87 \%$ ). The application of this method was demonstrated by the synthesis \\ of 2-(4-(tert-butyl)phenyl)benzo[b]thiophene 1,1-dioxide and (4-methoxyphenyl)(2-(4-methoxyphenyl) \\ benzo[b]thiophen-3-yl)methanone, which exhibit a fluorescence quantum yield of up to 1 and can be \\ used as a cannabinoid receptor ligand, respectively.
}

\section{Introduction}

As a crucial class of heterocyclic compounds, 2-substituted benzo $[b]$ thiophenes have broad biological properties ${ }^{1}$ and diversified applications in the field of materials science. ${ }^{2}$ They are usually considered as important structural motifs in pharmaceuticals and biologically active molecules. For example, as shown in Fig. 1, Bi-BTBT, raloxifene, and iPr-BTBT are examples of commercial drugs and organic semiconductors containing benzothiophene cores. ${ }^{3}$

The normal approaches to synthesize 2-substituted benzo[b] thiophenes are normally focused on a coupling cyclization

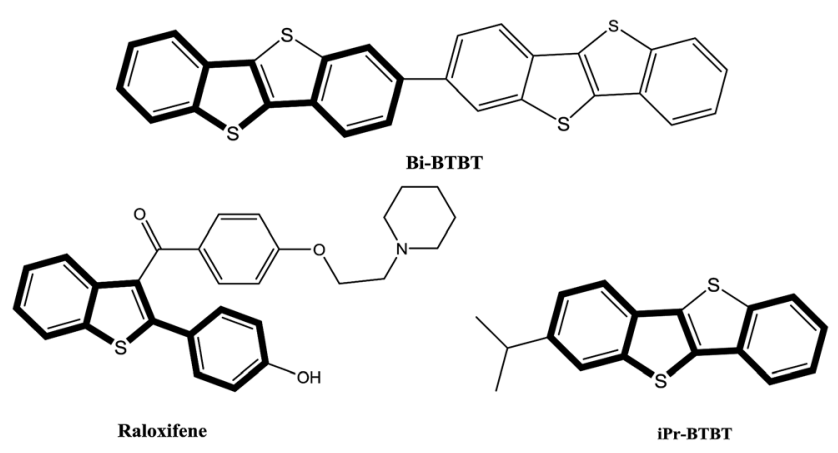

Fig. 1 Selected pharmaceutical and biologically active 2-substituted benzo[b]thiophenes.

${ }^{a}$ College of Chemistry, Sichuan University, Chengdu 610064, P. R. China. E-mail: zhouxiangge@scu.edu.cn; Fax: +86-28-85412904

${ }^{b}$ College of Chemistry \& Chemical Engineering, Yibin University, Yibin 644000, P. R. China

$\dagger$ Electronic supplementary information (ESI) available. See DOI: $10.1039 / \mathrm{c} 6 \mathrm{ra} 26611 \mathrm{~h}$ reaction of $o$-bromoalkynylbenzenes with various thiol surrogates upon lithium halogen exchange at $-78^{\circ} \mathrm{C}$ (Scheme 1a) $)^{4}$ or the annulation of alkynylbenzenes (Scheme 1b). ${ }^{5}$ While in the process of reporting this study, a similar study was reported by $\mathrm{Fu}$ and co-workers using the electrophilic cyclization of $o$ alkynyl thioanisole (Scheme 1c). ${ }^{6}$ However, the major obstacles of these methods are a result of the harsh reaction conditions or the limitation of the starting materials used.

On the other hand, the Sonogashira cross-coupling reaction ${ }^{7}$ between aryl or alkenyl halides with terminal alkynes in the presence of a transition-metal catalyst has become one of the most powerful methods to prepare alkyl-aryl and diarylsubstituted acetylenes. ${ }^{8}$ In a continuation of our study on catalytic Sonogashira cross-coupling reaction and synthesis of sulfur-containing heterocyclic compounds, ${ }^{9}$ herein we report

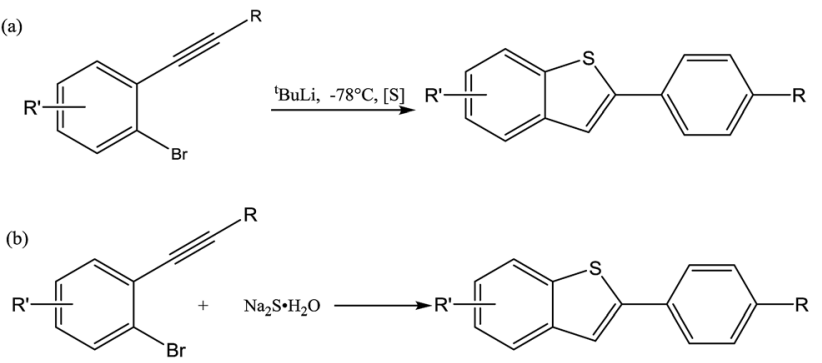

(c)

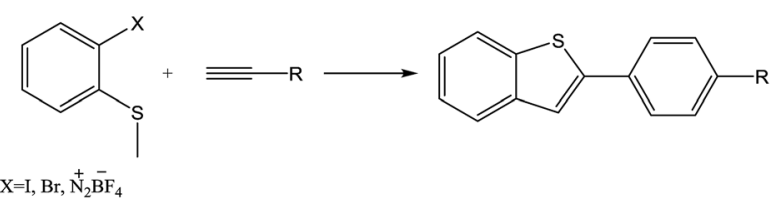

Scheme 1 Selected examples of the commonly used synthetic methods to prepare 2 -substituted benzo[b]thiophenes. 
the palladium-catalyzed synthesis of 2-substituted benzo[ $b]$ thiophenes using 2-halothiophenols and phenylacetylenes as starting materials.

\section{Results and discussion}

Our investigation started with the model substrates 2-iodothiophenol 1a and phenylacetylene 2a. As shown in Table 1, a variety of transition metal salts were tested and palladium acetate exhibited the best catalytic ability with a yield of $34 \%$ (Entries 1-8). Moreover, other metals including nickel, cobalt, and iron salts gave much less yields of $4 \%, 8 \%$, and $5 \%$, respectively (Entries 3, 4, and 5). In the case of copper salt, the coupling product between the alkyne was found to be the major product (Entries 1 and 2). ${ }^{10}$ The blank experiment further confirmed that no reaction occurred in the absence of a catalyst

Table 1 Optimization of the reaction conditions ${ }^{a}$<smiles>Sc1ccccc1I</smiles>

1a<smiles>C#Cc1ccccc1</smiles>

2a

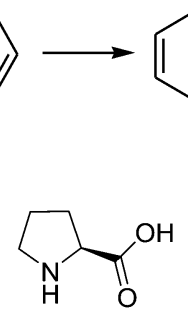

$\mathrm{PPh}_{3}$<smiles>c1ccncc1</smiles>

Pyridine
L-proline
TMEDA

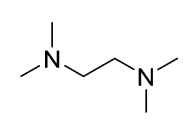

\begin{tabular}{|c|c|c|c|c|c|}
\hline Entry & Catalyst & Ligand & Additive & $T /{ }^{\circ} \mathrm{C}$ & Yield $^{b}(\%)$ \\
\hline 1 & $\mathrm{CuI}$ & - & - & 100 & 14 \\
\hline 2 & $\mathrm{CuCl}$ & - & - & 100 & Trace \\
\hline 3 & $\mathrm{NiCl}_{2}$ & - & - & 100 & 4 \\
\hline 4 & $\mathrm{CoCl}_{2} \cdot 6 \mathrm{H}_{2} \mathrm{O}$ & - & - & 100 & 8 \\
\hline 5 & $\mathrm{FeSO}_{4}$ & - & - & 100 & 5 \\
\hline 6 & $\mathrm{Pd}\left(\mathrm{PPh}_{3}\right) \mathrm{Cl}_{2}$ & - & - & 100 & 28 \\
\hline 7 & $\mathrm{Pd}\left(\mathrm{PPh}_{3}\right)_{4}$ & - & - & 100 & 21 \\
\hline 8 & $\mathrm{Pd}(\mathrm{OAc})_{2}$ & - & - & 100 & 34 \\
\hline 9 & - & - & - & 100 & Trace \\
\hline 10 & $\mathrm{Pd}(\mathrm{OAc})_{2}$ & - & AgOAc & 100 & 68 \\
\hline 11 & $\mathrm{Pd}(\mathrm{OAc})_{2}$ & - & $\mathrm{Ag}_{2} \mathrm{CO}_{3}$ & 100 & 66 \\
\hline 12 & $\mathrm{Pd}(\mathrm{OAc})_{2}$ & - & AgTFA & 100 & 71 \\
\hline 13 & $\mathrm{Pd}(\mathrm{OAc})_{2}$ & $\mathrm{PPh}_{3}$ & AgTFA & 100 & 75 \\
\hline 14 & $\mathrm{Pd}(\mathrm{OAc})_{2}$ & TMEDA & AgTFA & 100 & 81 \\
\hline 15 & $\mathrm{Pd}(\mathrm{OAc})_{2}$ & L-Proline & AgTFA & 100 & 69 \\
\hline 16 & $\mathrm{Pd}(\mathrm{OAc})_{2}$ & Pyridine & AgTFA & 100 & 72 \\
\hline 17 & $\mathrm{Pd}(\mathrm{OAc})_{2}$ & TMEDA & AgTFA & 105 & 82 \\
\hline 18 & $\mathrm{Pd}(\mathrm{OAc})_{2}$ & TMEDA & AgTFA & 110 & 85 \\
\hline 19 & $\mathrm{Pd}(\mathrm{OAc})_{2}$ & TMEDA & AgTFA & 115 & 84 \\
\hline 20 & $\mathrm{Pd}(\mathrm{OAc})_{2}$ & TMEDA & AgTFA & 120 & 84 \\
\hline $21^{c}$ & $\mathrm{Pd}(\mathrm{OAc})_{2}$ & TMEDA & AgTFA & 110 & 87 \\
\hline $22^{d}$ & $\mathrm{Pd}(\mathrm{OAc})_{2}$ & TMEDA & AgTFA & 110 & 87 \\
\hline $23^{e}$ & $\mathrm{Pd}(\mathrm{OAc})_{2}$ & TMEDA & AgTFA & 110 & 86 \\
\hline
\end{tabular}

${ }^{a}$ Reaction conditions: 2-iodothiophenol $1 \mathrm{a}(0.5 \mathrm{mmol})$, phenylacetylene 2a (4 equiv.), catalyst (10 mol\%), ligand $(20 \mathrm{~mol} \%)$, and additive $(1.1$ equiv.) in DMF ( $2 \mathrm{~mL})$ under $\mathrm{N}_{2}$ for $24 \mathrm{~h} .{ }^{b}$ Isolated yields. ${ }^{c} \mathrm{Pd}(\mathrm{OAc})_{2}$ $(15 \mathrm{~mol} \%) .{ }^{d} \mathrm{Pd}(\mathrm{OAc})_{2}(20 \mathrm{~mol} \%) .{ }^{e} \mathrm{Pd}(\mathrm{OAc})_{2}(25 \mathrm{~mol} \%)$. and ligand (Entry 9). Furthermore, silver salts were found to be beneficial to the reaction. In addition, AgTFA was shown to be the best one with a yield of $71 \%$ (Entries 10-12). Moreover, the ligand was also proved to promote the catalysis by up to $81 \%$ yield in the case of TMEDA (Entries 13-16). Lastly, screening the reaction temperature and catalyst loading indicated that $110{ }^{\circ} \mathrm{C}$ and $15 \mathrm{~mol} \%$ catalyst were optimal for the reaction with yields up to $87 \%$ (Entries 17-23). Hence, it was concluded that the best conditions were $15 \mathrm{~mol} \% \mathrm{Pd}(\mathrm{OAc})_{2}, 20 \mathrm{~mol} \%$ TMEDA, and 1.1 equiv. AgTFA in DMF at $110{ }^{\circ} \mathrm{C}$ for $24 \mathrm{~h}$.

With the optimal reaction conditions in hand, we then explored the scope of 2-iodothiophenols and alkynes. As shown in Scheme 2, different alkynes with either electron-withdrawing groups $(-\mathrm{F},-\mathrm{Br})$ or electron-donating groups $\left(-t \mathrm{Bu},-\mathrm{OCH}_{3}\right)$ can generate the desired products in yields from 41 to $78 \%$ under the standard conditions (3b-3e). Moreover, 2-iodothiophenols with various functional groups (such as $-\mathrm{F},-\mathrm{Cl}$, and $-\mathrm{CF}_{3}$ ) can also be successfully applied in this method and novel compounds such as $\mathbf{3 g}, \mathbf{3 h}$, and $\mathbf{3 i}$ were also obtained in around $50 \%$ yield, which have great potential, especially in pharmaceutical compounds and materials synthesis.

To further explore the potential application of this method, the reaction of 1a and $2 \mathrm{a}$ was scaled up to $10.0 \mathrm{mmol}$ in a $50 \mathrm{~mL}$ one-necked flask and the same efficiency was maintained (Scheme 3). The desired product can be obtained in $75 \%$ yield, which confirms its suitability for large-scale reaction.

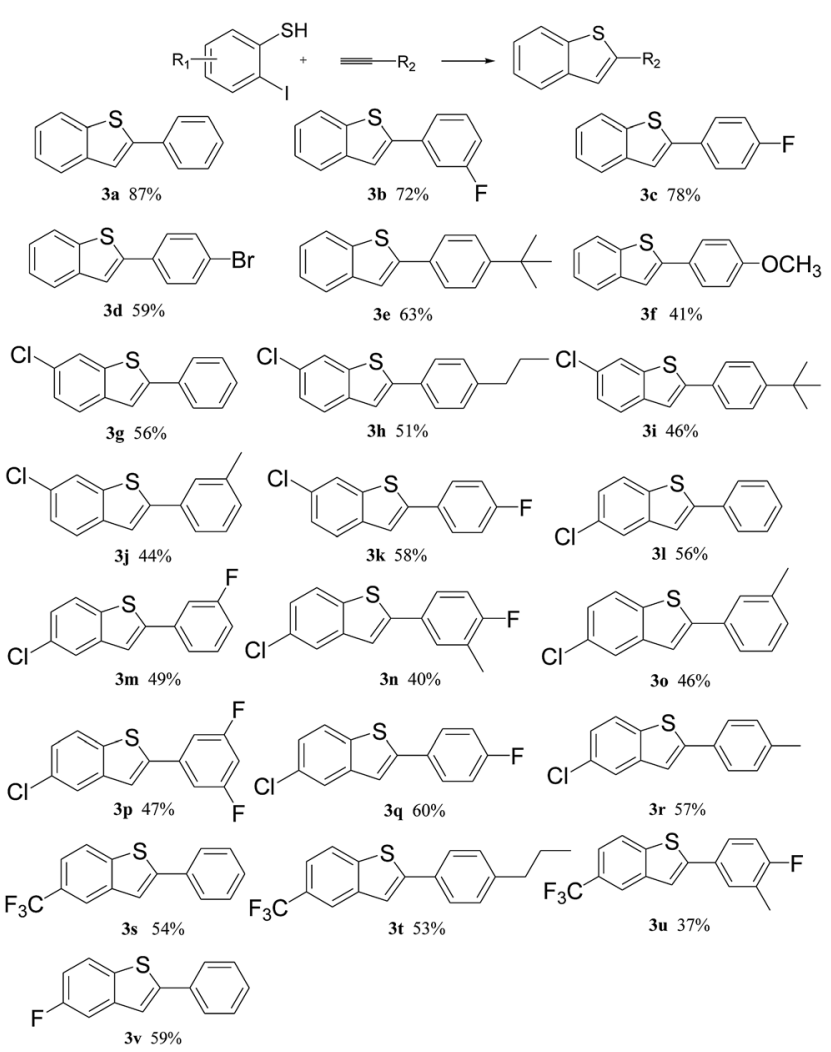

Scheme 2 The synthesis of different benzo[b]thiophenes. ${ }^{a, b}$ a Reaction conditions: 2-iodothiophenol $(0.5 \mathrm{mmol})$, alkyne (4 equiv.), $\mathrm{Pd}(\mathrm{OAc})_{2}$ (15 mol\%), TMEDA (20 mol\%), and AgTFA (1.1 equiv.) in DMF (2 $\mathrm{mL}$ ) under $\mathrm{N}_{2}$ at $110{ }^{\circ} \mathrm{C}$ for $24 \mathrm{~h}$. ${ }^{\mathrm{b}}$ Isolated yield. 
<smiles>Sc1ccccc1I</smiles>

1a $(1.18 \mathrm{~g}, 10 \mathrm{mmol})$

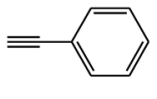

2a ( 4.0 equiv)

Standard Conditions
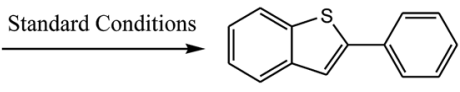

3a $75 \%$

Scheme 3 The gram scale reaction performed under the standard conditions.

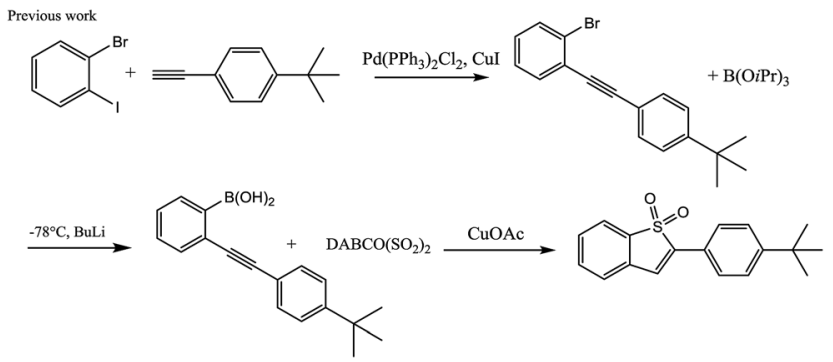

Our work

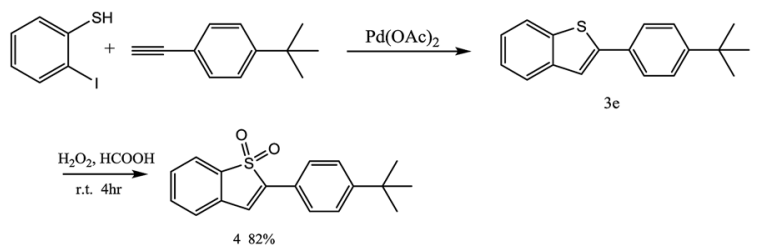

Scheme 4 A comparison of the synthesized compounds 4 and 5
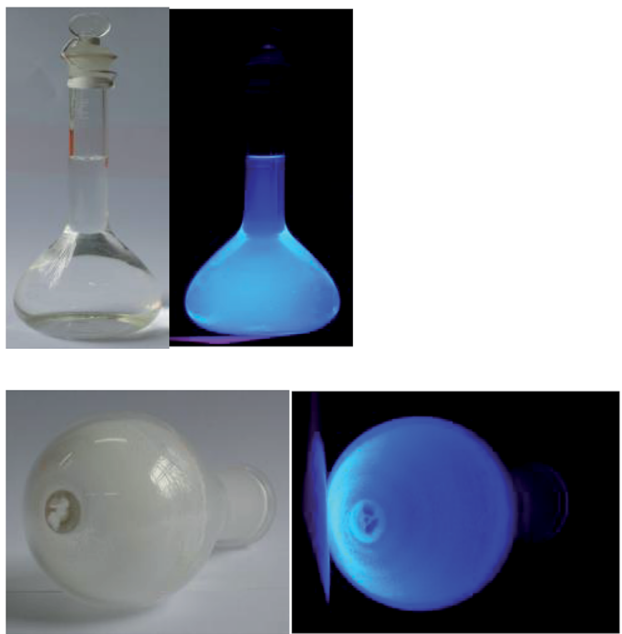

Fig. 2 Images of compound 4 in $\mathrm{MeCN}\left(1.0 \times 10^{-5} \mathrm{~mol} \mathrm{~L}^{-1}\right)$ and the solid state under sunlight (left) and under $360 \mathrm{~nm}$ UV light (right).

Furthermore, 2-(4-(tert-butyl)phenyl)benzo[b]thiophene 1,1dioxide 4 can be easily obtained after adding $\mathrm{H}_{2} \mathrm{O}_{2}$ into $3 \mathrm{e}$ at room temperature, which could shorten one step and uses milder reaction conditions when compared with those reported in the literature (Scheme 4). ${ }^{\mathbf{1 1}}$ Furthermore, Fig. 2 shows images of the compound 4 in MeCN and the solid state under sunlight (left) and under $360 \mathrm{~nm}$ UV light (right). Fig. 3 displays the absorption and emission spectra of compound 4 in MeCN (1.0 $\left.\times 10^{-5} \mathrm{~mol} \mathrm{~L}^{-1}\right)$. Note that compound 4 in MeCN exhibited an
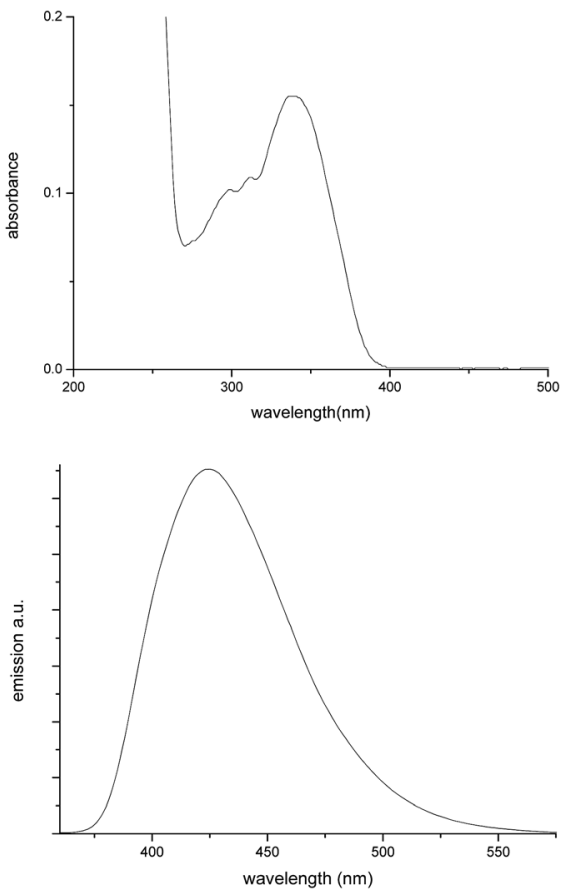

Fig. 3 The absorption and emission spectra of compound 4 in $\mathrm{MeCN}$ $\left(1.0 \times 10^{-5} \mathrm{~mol} \mathrm{~L}^{-1}\right)$.

unexpectedly high fluorescence quantum yield of up to 1 that was measured using quinine sulfate as a standard (quinine in $5.0 \times 10^{-5} \mathrm{~mol} \mathrm{~L}^{-1}$ sulfuric acid), which would shows broad prospects for use in organic light-emitting diodes (OLEDS).

Besides this, we also tried to synthesize the benzothiophene derivative (4-methoxyphenyl)(2-(4-methoxyphenyl)benzo[ $b]$ thiophen-3-yl)methanone $\mathbf{5}$ using product $\mathbf{3 f}$ as the starting material in a higher yield than that reported in the literature. Compound 5 has been reported as a new cannabinoid receptor ligand and an intermediate of thrombin inhibitor. ${ }^{\mathbf{1 2}}$

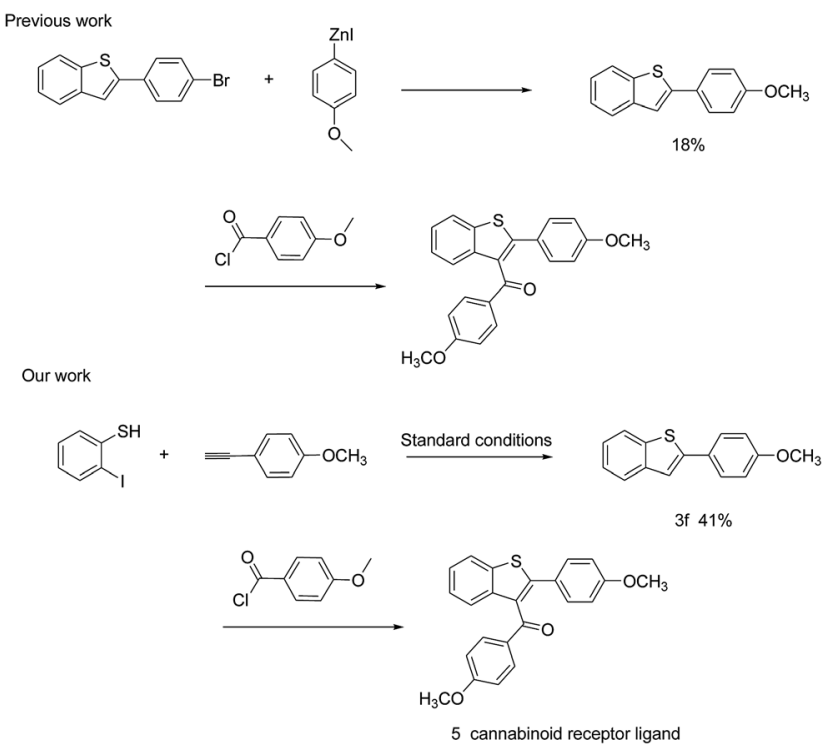




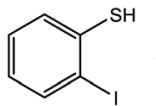

1a

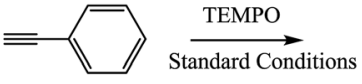

$2 \mathrm{a}$

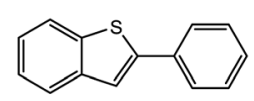

3a $80 \%$
Scheme 5 The radical/electron trapping experiment.

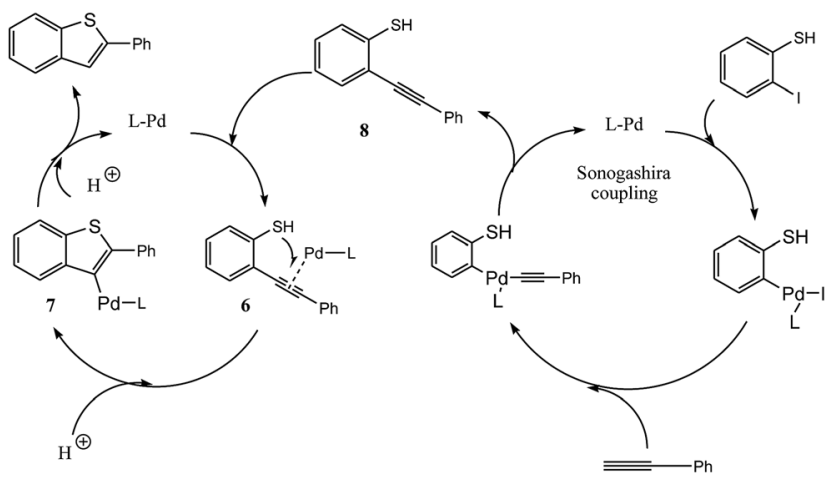

Scheme 6 The proposed reaction pathway.

To explore the reaction pathway, a radical trapping experiment was carried out by the addition of a typical radical scavenger TEMPO (2,2,6,6-tetramethylpiperidine-1-oxyl). Almost the same yield $(80 \%)$ indicated that the reaction did not involve a radical intermediate (Scheme 5). Furthermore, the intermediate 2-(phenylethynyl)benzenethiol 8 was observed by GC/MS in the reaction between 2 -iodothiophenol and phenylacetylene after 3 hours.

Based on the experimental and literature data, we proposed a reaction pathway for the palladium-catalyzed synthesis of 2substituted benzo[ $b]$ thiophenes from 2-halophenols and alkynes, which consists of two steps: the Sonogashira coupling of 2-halothiophenol with the alkyne and the subsequent cyclization of 2-alkynylthiophenol (Scheme 6). First, the Pd-catalyzed Sonogashira coupling of 2-halothiophenol with the alkyne affords intermediate 8. Then, coordination of Pd with intermediate $\mathbf{8}$ may provide complex $\mathbf{6}$, whose subsequent addition to the $\mathrm{C}-\mathrm{C}$ triple bond gave intermediate 7 . Protonation of intermediate 7 results in the formation of benzo $[b]$ thiophene and the regenerated Pd-catalyst.

\section{Conclusions}

In summary, we developed an efficient catalytic system using 2iodothiophenols as the starting material for the synthesis of a variety of 2 -substituted benzo $[b]$ thiophenes. This protocol involves the following advantages: easily available starting materials and simple operations with moderate to good yields, and will contribute a new optional route for the construction the benzo $[b]$ thiophene ring. Moreover, the application of this method was considered as an example by the synthesis of 2-(4(tert-butyl)phenyl)benzo[b]thiophene 1,1-dioxide and (4methoxyphenyl)(2-(4-methoxyphenyl)benzo[b]thiophen-3-yl) methanone, which exhibit a fluorescence quantum yield up to 1 and use as a cannabinoid receptor ligand, respectively.

\section{Acknowledgements}

We are grateful to the Natural Science Foundation of China (grant no. 21372169, 21472128, J1310008). We also acknowledge the comprehensive training platform of the specialized laboratory, College of Chemistry, Sichuan University for HRMS analysis.

\section{Notes and references}

1 For selected recent examples, see: (a) L. Berrade, B. Aisa, M. Ramirez, S. Galiano, S. Guccione, L. Moltzau, F. Levy, F. Nicoletti, G. Battaglia, G. Molinaro, I. Aldana, A. Monge and S. Perez-Silanes, J. Med. Chem., 2007, 50, 5644; (b) A. Venturelli, D. Tondi, L. Cancian, F. Morandi, G. Cannazza, B. Segatore, F. Prati, G. Amicosante, B. Shoichet and M. Costi, J. Med. Chem., 2011, 54, 3086; (c) R. Romagnoli, P. Baraldi, M. Carrion, C. Cara, D. Preti, F. Fruttarolo, M. Pavani, M. Tabrizi, M. Tolomeo, S. Grimaudo, A. Cristina, J. Balzarini, J. Hadfield, A. Brancale and E. Hamel, J. Med. Chem., 2007, 50, 2273; (d) J. Chabert, B. Marquez, L. Neville, L. Joucla, S. Broussous, P. Bouhours, E. David, S. Pellet-Rostaing, B. Marquet, N. Moreau and M. Lemaire, Bioorg. Med. Chem., 2007, 15, 4482.

2 (a) J. Gao, R. Li, L. Li, Q. Meng, H. Jiang, H. Li and W. Hu, Adv. Mater., 2007, 19, 3008; (b) V. Bren, A. Dubonosov, V. Minkin, A. Tsukanov, T. Gribanova, E. Shepelenko, Y. Revinsky and V. Rybalkin, J. Phys. Org. Chem., 2007, 20, 917; (c) T. Zhang, J. O'toole and C. Proctor, J. Sulfur Chem., 1999, 22, 1.

3 (a) M. Abe, T. Mori, I. Osaka, K. Sugimoto and K. Takimiya, Chem. Mater., 2015, 27, 5049; (b) B. Fox and S. Olson, J. Med. Chem., 2015, 58, 5256; (c) G. Schweicher, V. Lemaur, Y. Geerts and Z. Bao, Adv. Mater., 2015, 27, 3066; (d) E. Yamaguchi, C. Wang, A. Fukazawa, T. Higashiyama and S. Yamaguchi, Angew. Chem., Int. Ed., 2015, 54, 4539; (e) E. Amir, M. Murai and C. Hawker, Chem. Sci., 2014, 5, 4483; ( $f$ ) X. Peng, J. Deng and H. Xu, RSC Adv., 2013, 3, 24146; $(g)$ S. Kawai, T. Nakashima and T. Kawai, J. Mater. Chem., 2009, 19, 3606; (h) S. Chen, W. Li, X. Li and W. Zhu, RSC Adv., 2015, 5, 87626.

4 (a) H. Sashida, K. Sadamori and T. Tsuchiya, Synth. Commun., 1998, 28, 713; (b) Y. Wang, S. Parkin and M. Watson, Org. Lett., 2008, 10, 4421; (c) K. Takimiya, Y. Konda, H. Ebata, N. Niihara and T. Otsubo, J. Org. Chem., 2005, 70, 10569.

5 (a) T. Kashiki, S. Shinamura, M. Kohara, E. Miyazaki, K. Takimiya, M. Ikeda and H. Kuwabara, Org. Lett., 2009, 11, 2473; (b) L. Sun, C. Den, R. Tang and X. Zhang, J. Org. Chem., 2011, 76, 7546.

6 L. Gao, B. Chang, W. Qiu, L. Wang and X. Fu, Adv. Synth. Catal., 2016, 358, 1202.

7 (a) K. Sonogashira, Y. Tohda and N. Hagihara, Tetrahedron Lett., 1975, 16, 4467; (b) H. Diek and F. Heck, Organomet. Chem., 1975, 93, 295; (c) L. Cassar, Organomet. Chem., 1975, 93, 253; (d) M. Miller and C. Johnson, J. Org. Chem., 1997, 
62, 1582; (e) S. Thorand and N. Krause, J. Org. Chem., 1998, 63, 8551; $(f)$ A. Chandra and B. Singh, Tetrahedron, 2008, 64, 11680.

8 (a) T. Magdesieva, O. Nikitin, A. Yakimansky, M. Goikhman and I. Podeshvo, Electrochim. Acta, 2011, 56, 3666; (b) L. Wu, X. Shi, X. Xu, F. Liang and G. Huang, J. Chem. Sci., 2011, 123, 697; (c) Y. Liang, S. Tang, X. Zhang, L. Mao, Y. Xie and J. Li, Org. Lett., 2006, 8, 3017.

9 (a) L. Yu and X. Zhou, Eur. J. Org. Chem., 2010, 29, 5560; (b) F. Ke, Z. Li and X. Zhou, Org. Lett., 2011, 13, 454; (c) H. Deng, Z. Li and X. Zhou, Chem.-Eur. J., 2012, 18, 4840; (d) R. Che, Z. Li and X. Zhou, Chem.-Eur. J., 2014, 20, 7258.
10 (a) C. Meng and R. Yuan, ACS Catal., 2015, 5, 3760; (b) P. Röse, K. Harms and G. Hilt, J. Org. Chem., 2015, 80, 7311; (c) Y. Liu and J. Wan, Tetrahedron Lett., 2013, 54, 3953.

11 (a) J. Liu, A. Narita, S. Osella, W. Zhang, D. Schollmeyer, D. Beljonne, X. Feng and K. Müllen, J. Am. Chem. Soc., 2016, 138, 2602; (b) R. Mao, D. Zheng, H. Xia and J. Wu, Org. Chem. Front., 2016, 3, 693.

12 (a) J. Romero-Parra, J. Mella-Raipa, M. Torres, R. Escobar, M. Faúndez and C. David Pessoa-Mahana, Eur. J. Med. Chem., 2016, 124, 17; (b) D. J. Sall, D. L. Bailey, J. A. Bastian and M. Zhang, J. Med. Chem., 2000, 43, 649. 